\title{
ASEAN LABOR MARKET INTEGRATION AND ITS SOCIAL EFFECTS FOR UNSKILLED LABOR MIGRATION
}

\author{
Ignatia Bintang Filia Dei Susilo \& Dian Pujiatma Vera Subchanifa \\ Universitas Gadjah Mada, Indonesia \\ Email: verazzura@gmail.com
}

\begin{abstract}
Abstrak: Integrasi Pasar Tenaga Kerja ASEAN dan Dampak Sosial Terhadap Migrasi Tenaga Kerja Tidak Terampil. Sebagian besar negara-negara anggota ASEAN membutuhkan tenaga kerja profesional dan tenaga kerja yang tidak terampil. Tenaga kerja profesional memiliki hak-hak khusus, fasilitas, dan berbagai keuntungan, sedangkan tenaga kerja tidak terampil hanya memiliki sedikit hak dan lebih jarang menjadi topik utama kerjasama integrasi antar negara. Artikel ini akan membahas dampak sosial integrasi, terutama bagi tenaga kerja tidak terampil, dengan mengaitkan hubungan antara migrasi dan remittance di ASEAN, sektor tenaga kerja, dan pengelolaan imigrasi yang dilakukan pemerintah. Sebagian besar negara anggota ASEAN harus meningkatkan standar kinerja dan gaji, menyediakan pelatihan, dan meningkatkan tingkat pendidikan. Terdapat beberapa dampak sosial yang muncul. Namun, beberapa dampak tersebut akan dapat ditangani apabila pemerintah memiliki komitmen dalam menerapkan kebijakannya.
\end{abstract}

Kata kunci: integrasi ekonomi, remittance, pekerja migran, tenaga kerja tidak terampil

\begin{abstract}
ASEAN Labor Market Integration and Its Social Effects for Unskilled Labor Migration. Member states of ASEAN mainly needed two criteria of foreign labor: highly skilled professionals or its counterpart, unskilled workers. High-skilled professionals are provided with some rights and benefits. Unskilled migrants are equipped with very limited rights and hardly subject to integration approaches. This paper will discuss the social effect of integration, notably the unskilled labor, by linking migration and remittance in ASEAN, labor based on sectored pattern, and immigration governance. Countries need to improve working conditions and wages, provide professional training and improve education for every level of workers. There are some social effects but can be managed if the governments committed to their policy.
\end{abstract}

Keywords: economic integration, remittance, migrant worker, unskilled labor

\section{INTRODUCTION}

ASEAN Community is a realization form of the ASEAN integration purpose. There are three pillars of ASEAN Community: ASEAN Economic Community (AEC), ASEAN SocioCultural Community (ASCC), and ASEAN Political-Security Community (APSC). AEC will transform ASEAN into region with free movement of goods, services, investment, skilled labor, and freer flow of capital
(ASEAN, 2015a). ASCC will make a peopleoriented and socially responsible community with a view to achieving enduring solidarity and unity among the people and ASEAN countries (ASEAN, 2009b). AEC emphasize freer movement of skilled labor while the ASCC enhanced the well-being, livelihood, and welfare of the people.

Member states of ASEAN mainly needed two criteria of foreign labor: highly skilled 
professionals or its counterpart, low-skilled workers. High-skilled professionals are provided with some rights and benefits, facilitated, and widely announced as target of integration policies. Low-skilled migrants are equipped with very limited rights, not facilitated, ignored, and hardly subject to integration approaches. This paper will see the social effect of integration, mainly for lowskilled and unskilled labor, by linking migration and remittance in ASEAN. The management of labor flows will be discussed also.

\section{LABOR MIGRATION PATTERN AND REMITTANCE}

Globalization connects countries, not only through the channel of trade, technology, and capital, but also through the flow of labor between countries. Total labor force for both skilled and low skilled grows more and much more, flows between regions, countries and continents. On the other hand, with increasing competition, the gap between the country's GDP and income per capita are also getting bigger. For example, Singapore's GDP per capita almost 51 times higher than Cambodia. This fact leads people from lessdeveloped countries to seek opportunities in more-developed countries, where the opportunities are widely available.

Based on its growth, ASEAN can be divided into three subsystems (Battistella and Asis, 2003). First subsystem is Sijori Triangle including Singapore, Johor in Malaysia and Riau in Indonesia. Brunei, Indonesia, Malaysia and Philippines established East ASEAN growth area (BIMPEAGA). Northern ASEAN sub-region covered Malaysia, Indonesia and Thailand. Each of these sub-regions planned to facilitate trade, capital and labor flow (Kaur, 2010). Attempts to increase labor competitiveness have been initiated and implemented, for example as written in Work Plan of the Senior Labour Officials Meeting Working Group on Progressive Labour Practices to Enhance the Competitiveness of ASEAN (SLOM-WG) (ASEAN, 2009b).

Lack job opportunities, less-developed countries such as Thailand, Philippines and Indonesia encourage its citizens to migrate. Therefore, they can sustain the life of their families. On average, most low-skilled workers in Indonesia and Vietnam work under \$1 daily salary. Cambodia and Laos, also half of Indonesia's population, lives below the poverty line with $\$ 2$ daily income. It encourages these people to earn a bigger salary and venture abroad.

Based on the number of immigrants and emigrants, ASEAN countries can be divided into two categories. Philippines, Cambodia, Myanmar, Lao PDR, Vietnam and Indonesia are migrants sending countries. These countries have high numbers of emigrant. Singapore, Brunei, Malaysia and Thailand are countries with high level of immigrant. Singapore, Brunei, Malaysia act as the main receiver for migrant workers coming from Indonesia and Philippines. Thailand is the main destination for migrant workers from countries where the Mekong River flows, such as Myanmar, Cambodia, Lao PDR and Vietnam (Kaur, 2010).

World Bank's migration data of ASEAN countries from 1960 to 2013 shown that Thailand, Malaysia, and Singapore have rising migration trend. Every year, number of foreign visiting those countries has risen. The 
Table 1. Gross domestic product per capita in ASEAN, at current prices (nominal) as of August 2015 in US\$; at current market prices

\begin{tabular}{|c|c|c|c|c|c|c|}
\hline Country & 2009 & 2010 & 2011 & 2012 & 2013 & 2014 \\
\hline Singapore & $38,577.3$ & $46,570.0$ & $53,117.0$ & $54,578.2$ & $55,979.8$ & $56,286.8$ \\
\hline Brunei Darussalam & $28,454.0$ & $32,062.9$ & $42,431.5$ & $42,445.5$ & $44,560.3$ & $41,424.4$ \\
\hline Malaysia & $7,215.6$ & $8,514.8$ & $9,962.1$ & $10,345.9$ & $10,420.5$ & $10,784.1$ \\
\hline Thailand & $3,946.6$ & $4,743.2$ & $5,116.0$ & $5,391.3$ & $5,678.7$ & $5,436.1$ \\
\hline Indonesia & $2,359.2$ & $2,988.0$ & $3,498.2$ & $3,563.8$ & $3,460.8$ & $3,900.5$ \\
\hline Viet Nam & $1,232.4$ & $1,337.8$ & $1,543.0$ & $1,755.3$ & $1,908.6$ & $2,054.8$ \\
\hline Philippines & $1,828.6$ & $2,127.1$ & $2,339.2$ & $2,567.8$ & $2,706.9$ & $2,816.0$ \\
\hline Lao PDR & 913.0 & $1,079.3$ & $1,262.4$ & $1,442.7$ & $1,612.7$ & $1,729.7$ \\
\hline Myanmar & 456.0 & 685.9 & $1,126.7$ & $1,189.8$ & $1,208.7$ & $1,277.7$ \\
\hline Cambodia & 735.1 & 785.1 & 881.7 & 951.5 & $1,018.3$ & $1,104.5$ \\
\hline ASEAN & $2,601.9$ & $3,159.9$ & $3,691.5$ & $3,861.2$ & $3,919.1$ & $4,135.9$ \\
\hline ASEAN 6 ${ }^{1 /}$ & $3,265.5$ & $3,975.7$ & $4,540.6$ & $4,715.1$ & $4,754.7$ & $5,005.1$ \\
\hline CLMV $^{2 /}$ & 900.6 & $1,047.9$ & $1,339.9$ & $1,490.6$ & $1,594.1$ & $1,709.6$ \\
\hline \multicolumn{7}{|c|}{ Data is computed by dividing GDP in US dollar term by the projected midyear population for the respective year. } \\
\hline 1/ ASEAN 6 consis & nei Darussala & donesia, Mala & lippines, Sin & and Thailan & & \\
\hline
\end{tabular}

Source: ASEAN (2015b)

other countries such as Brunei Darussalam, Cambodia, Lao PDR, Myanmar, Philippines, and Vietnam showing fluctuation in the number of migrants. Therefore, the fluctuation is not extreme. In case of Indonesia, World Bank's data shown that the number of migration decline, overtime. Indonesia's resident is more preferred to go abroad (Migration Policy Institute, 2013).

Thailand needed skilled workforce and issued regulations for foreign skilled labor recruitment in 1978. In the 1990s, Thailand has become highly depend on low-skilled labor to support the development of the manufacturing sector and agricultural commodities for export. Among its neighbors, Thailand recently has the highest number of immigrants. In 2013, Thailand make the highest rank of migrant with more than 4 million people come to this country. This number has shown Thailand's openness to the world, especially the other ASEAN countries as its commitment toward AEC. Thailand gives its intention to attract $a$ significant number of professionals from other ASEAN countries, leading to a direct positive effect on the economy (Yeoh \& Mirriam, 2014). In 2006, foreign labor in Thailand is about $2.3 \%$ of the total workforce. Percentage of foreign labor varied with small deviation, and until 2013 labor migration about $3 \%$ of the total workforce.

Singapore's immigration framework addressed to recruit professional workers and entrepreneurs. Professional workers in Singapore are offered residency, health subsidy, education and family allowance. Professional migrants mainly come from Malaysia, United States, Australia, Britain, Japan, South Korea, China and India (Yeoh \& Lin, 2012). Singapore also has some policies touching low-skilled workers, even though Singapore do not have agricultural sector like Malaysia and Thailand. Therefore, Singapore commits to intensify manufacturing sector. Low-skilled migrants in Singapore mainly work on manufacture sector, constructions, shipping industry, domestic work, care 
giving and other menial occupations (Kaur, 2010). Again, the immigration framework has been designed to attract professional workers, not low-skilled one.

Even though Singapore more concerned on importing and integrating highly skilled labor, such as business investors and professionals, there are also many immigrants worked as domestic workers. Majority foreign workforce comes from Indonesia and the Philippines. Unskilled female migrants are work as domestic workers. Low and unskilled male migrants are found mainly in the construction industry.

In 2008, Brunei Darussalam have 127,400 labor, 95,900 among them are immigrants from its neighbor countries such as Malaysia, Indonesia, and Thailand $\mathbf{3} 75.3 \%$ of total labor). In 2009 there are 121,200 labor, 89,900 among them are immigrants $(74.2 \%$ of total labor). In 2010 there are 117,200 labor, 87,100 among them are immigrants (74.3\% of total labor). Almost three fourth of its labor originated outside the nation. It is realistic that countries such as Brunei, Singapore, and Malaysia have significant amount of immigrant labor because the other ASEAN countries' workers are seeking for opportunity in more-developed countries.

Only $0.86 \%$ of Cambodia's labor in 2008 is immigrants. In 2010, this number has risen to $0.79 \%$, but in 2012 , the percentage declined to $0.70 \%$. Nearly all labor in Lao PDR is its own citizen. In 2013, there are 3,600 foreign labor forces in Vietnam.

Malaysia was a labor exporter and importer. In 1984, Malaysia signed a bilateral agreement (Medan Agreement) with
Indonesia to regulate supply of Indonesian migrant workers in agricultural and domestic workers. In 1985, Philippines and Malaysia signed an agreement regarding the recruitment of domestic helpers from the Philippines (Kaur, 2006). In 1987 to 1993, Malaysia changed its position from net labor exporter to a net labor importer. From 2006 until 2009, Malaysia has consistent percentage of migrant labor. The percentage of foreign labor from total labor is always 9.9\%. In 2010, the percentage of foreign labor increase to $14.1 \%$ from total labor. After 2010, the percentage varied at $13 \%$. Moreover, in 2013, foreign worker is $13.4 \%$ from total labor in Malaysia. Malaysia uses many migrant labors, since 1975 . Nowadays, Malaysia hires foreign workers at most.

Philippines labor force has increased since 2007. The number has risen from about 33.5 million in 2007 to about 38 million in 2013. Even though there are many labors in Philippines, the amount of foreign labor in Philippines is relatively small. There is also small amount of migrant visiting Philippines. From 1960, the number of migrants never reaches 400.000. In 2013, there are only 213,150 immigrants in Philippines.

By the process of economic growth, some ASEAN countries change from net senders of workers to net recipients such as Malaysia and Thailand. Malaysia and Thailand have been through some processes in growing their economic. Both of these countries develop their infrastructure, labor management, and real sectors. On the contrary, Philippines, Indonesia, Vietnam, Lao PDR and Cambodia intensify emigration to increase welfare. With high level of openness, the same items will be worth the 
Table 2. Emmigrants and Remittance Rank

\begin{tabular}{clcl}
\hline $\begin{array}{c}\text { Based on number of emmigrants } \\
\text { (World Bank, 2013) }\end{array}$ & \multicolumn{2}{c}{$\begin{array}{c}\text { Based on remittance } \\
\text { (World Bank, 2014) }\end{array}$} \\
\hline Rank & Country & Rank & Country \\
\hline 1 & Philippines & 1 & Philippines \\
2 & Indonesia & 2 & Viet Nam \\
3 & Myanmar & 3 & Indonesia \\
4 & Viet Nam & 4 & Thailand \\
5 & Malaysia & 5 & Malaysia \\
6 & Lao PDR & 6 & Myanmar \\
7 & Cambodia & 7 & Cambodia \\
8 & Thailand & 8 & Lao PDR \\
9 & Singapore & 9 & Singapore \\
10 & Brunei Darussalam & 10 & Brunei Darussalam \\
\hline
\end{tabular}

same in every country. Immigration reduces law of one-price deviations and promotes price convergence. Immigrants tend to move to high-wage destinations (Zachariadis, 2012).

Based on data from the World Bank in 2013, Philippines is the ASEAN country that gained the highest remittances, followed by Vietnam, Indonesia, and Thailand. While the countries receive small amount of remittances are Singapore and Brunei Darussalam, because the number of people worked outside the borders is very small. Rationally, a country with a high population of emigrants can obtain high remittance. Countries with a low population of emigrants will receive low remittance. However, there are countries with a high population of emigrants but get low remittance. There are also some countries with low emigrants but get high remittance. Indonesia, Myanmar and Lao PDR are ASEAN member countries that have a high population of emigrants, but obtained remittance at a low state. This could be happened because majority of the labor force is low skilled or unskilled.

Based on World Banks data, Malaysia have biggest remittance outflow among its neighbors in ASEAN (USD 2,621 million in 2013). After 2009 crises, the number of migrant workers decreased, as well as its remittance outflow. Once the economy has improved, the number of migrant workers started to increase which makes its remittance outflow increasing every year from 2011. Thailand also has high number of remittance outflow and places second after Malaysia. Most of its migrants come from Cambodia, Vietnam, and Philippines. Indonesia placed third. Indonesia is a country that has fairly balanced remittance inflow and outflow. Workforces that move inside or outside of Brunei Darussalam and Singapore are relatively small compared to the other countries. Therefore, their remittance outflows also small. Overall, ASEAN member countries that have gained more remittance inflow than outflow are Philippines, Vietnam, Indonesia, Thailand, Myanmar, Cambodia, and Lao PDR. Malaysia and Brunei Darussalam are ASEAN member countries that have higher remittance outflow than inflow.

Productivity varies greatly and correlates with the skills of the workforce. Annual output per Thailand worker is nearly four 
times the level of Cambodian worker. Therefore, even Thailand has lower rank $\left(7^{\text {th }}\right)$ based on the number of emigrants under Cambodia $\left(6^{\text {th }}\right)$, the remittance obtained by Thailand is ranked higher $\left(4^{\text {th }}\right)$ than Cambodia $\left(7^{\text {th }}\right)$.

Philippines ranked one both from the number of emigrants and remittance in 2013. Most people from this country migrated both inside and outside ASEAN. In ASEAN, many Philippines labor worked in Malaysia. Seeing the importance of remittance, the government gives adequate protection and training so that every type of labor, especially the service sector, adaptable and able to compete with labor from the other countries. The importance of remittance emphasizes the growing importance of labor migration within ASEAN nations.

Indonesia placed second in terms of emigrants but placed third, below Vietnam (which was second), in terms of remittance. Since 2005, remittances have been higher than inflows of development aid, but not as its main income. The remittance though, very important to the poor.

\section{SECTORAL PATTERN}

Labor can be divided into three major sectors, namely labor working in the industry sector, agriculture, and service. According to data from the International Labor Organization, Lao PDR is a country with the most labor in the agricultural sector, Malaysia with a workforce of at most in industry sector and Singapore with most workers in the service sector in ASEAN. Das (2014) see that there are some impacts from labor market in MEA. There are positive and negative impacts. First, there is a structural change on domestic economy. Each ASEAN member country will affect the labor market then. There is reallocation of labor resources from less productive sector towards more productive ones. The second impact is demand shift for certain jobs. The jobs available will be more complex, and required skilled labor. Lowskilled and unskilled labor will be affected.

Based on International Labor Organization (ILO) and Asian Development Bank (ADB) data on 2014, Brunei Darussalam is a country at most workers work in the service sector. From 1991 to 2001, 72\% of the workforce in Brunei Darussalam worked in the service sector, $26 \%$ worked in the industrial sector and $2 \%$ of the workforce worked in the agricultural sector. From 2004 to $2012,55 \%$ of the workforce in Cambodia worked in the agricultural sector, $15 \%$ worked in the industrial sector, and $30 \%$ worked in the service sector.

In 1992 to 2013 there were about 30\% people working in the Malaysian industrial sector. From 1992, Malaysian workforce mainly works in service sector. The case is similar to Philippines. Majority of Philippines people works in service sector (about 47\% from 1992 until 2013). Therefore, about 47\% of the workforce in the Philippines to work in the service sector and $14 \%$ of labor work in the Philippines industry sector.

Singapore is a country where the most of its labor works also in service sector. In 1992 through 2013, on average, workers who work in service sector is $72 \%$. As many as $27 \%$ of employees working in industrial sector. Very few people worked in agricultural sector (1\%). On the same period, the average of Thailand labor who worked in the agricultural 
sector is $49 \%$. $32 \%$ of the workforce in Thailand worked in the service sector and $19 \%$ in the industry sector.

Indonesia was an agricultural country. In $1992,55 \%$ of Indonesian labor worked in the agricultural sector. The percentage decreased to $47 \%$ in 2003 , then fell to $35 \%$. Therefore, during 1992 to 2013, the number of workers in the industrial sector rose from $4 \%$ to $20 \%$. Indonesian labor working in the service sector is seen rising from $31 \%$ to $45 \%$ during 1992 through 2013. Nowadays, its people works majority in the service sector.

In 1995, 84\% of Lao PDR labor force worked in the agricultural sector, $5 \%$ of the workforce employed in industry and $11 \%$ of employees worked in the service sector. In 2010 , workers who worked in the agricultural industry fell to $71 \%$, employment in the industrial sector rose to $8 \%$ and the workers who work in the service sector rose to $21 \%$. Until present, most of Lao PDR labor force still works in the agricultural sector.

In Vietnam, most its labor work in agricultural sector. In 1996, $70 \%$ of the workforce employed in agriculture, in 2003, the workforce employed in agriculture fell to $60 \%$ and by 2013 , the number of workers who work in the agricultural sector fell to 47\%. Since 1996 until 2013, on average, as much as $15 \%$ of labor in Vietnam working in industry sector and around $25 \%$ of the workforce employed in the service sector.

Based on International Labor Organization (ILO) and Asian Development Bank (ADB) data on 2014, with the enactment of $A E C$, labor in Cambodia will increase about 1 million people, which will grow $10 \%$ from it is in 2015 . Labor in Vietnam will grow up to 3.1 million (6\%). Lao PDR will increase its labor about 3\% and Indonesia 1.8\% (1.9 million people). The biggest employed sector is the service sector (International Labour Organization (ILO) and Asian Development Bank (ADB), 2014).

\section{IMMIGRATION POLICIES AND GOVERNANCE OF LABOUR MIGRATION}

Low-skilled labor competition has been higher since there is higher preference to seek workers from countries outside ASEAN, such as India. Large amount of low-skilled labor demand has been resulting on the spreading of migrant labor agencies. The high competition among these agencies leads them to earn low profit. On the other side, the agency is required to pay transportation cost, accommodation, training, and employment. As a result, these costs charged directly to the employer of the workers. The employer must issue to pay the initial costs of labor agency, which is the same as four months' worth of domestic worker. Finally, low-skilled and unskilled workers do not receive a salary during the first four months. To anticipate unwanted things, employers also hold migrant's passport or documents as collateral. Workers from less-developed countries go to more-developed countries. Many of these labors are un-skilled and interested to work as domestic workers. The recruitment of skilled and unskilled labor is distinguished. Settlement is not permitted for unskilled workers, who are typically employed on temporary contracts. Even though they know that the cost of immigration is expensive and all of the consequences, these workers insist seek his fortune abroad. Then, one problem triggers other problems. 
Three laws, namely the Immigration Act, the Employment of Foreign Workers' Act and the Penal Code, govern management of foreign labor in Malaysia. Malaysia also targeted recruitment professionals in business and engineering. There are two different types of visas for professional workers and low-skilled workers. Expatriates get a visa called employment pass, while lowskilled workers and house cleaners get a visa called visit pass. Low-skilled labor recruited to stay for one-year period, which renewed every year for five years. The low-skilled labor works in manufacturing sector, construction, agriculture, services and housekeeper.

Weak structure of employment policy in Malaysia gives rise to vulnerability and marginalization for low-skilled workers. The number of government agencies involved in the recruitment process led to the convoluted bureaucratic process (Kaur, 2010). Lack of coordination between the State Departments led to weak supervision of low-skilled workers. As a result, low-skilled workers are difficult to obtain justice and protection. The problems evolve, such as Indonesia's unskilled domestic workers cases in Malaysia. Governments of both sides have done coordination on the issues. In 2006, cooperation of both countries resulted in an agreement governing the contract criterions and standards for Indonesian domestic workers in Malaysia.

Although the rules have been set, detention of labor wages are still going on. Most low-skilled domestic workers in Malaysia are not paid during the first seven months to reimburse the employers cost which was given to labor agency. Although there have been regulations of both countries, the issue of foreign labor is still difficult to resolve. In 2009, Indonesia reported a thousand cases of labor abuse. Therefore, Malaysia recorded only fifty cases of labor abuse (The Straits Times, 13 July 2009).

Before 2000s, Thailand has no laws, such as Malaysia and Singapore, which regulates the provisions of the labor force. Foreign lowskilled workers must enroll and register themselves annually. This system causes a rising number of illegal workers. In 2000, the International Labor Organization, in collaboration with the United Kingdom's Department for International Development and United Nation's Human Security Fund (funded by Japan), launched the United Nations Inter-Agency Project on Human Trafficking (UNIAP) (Kaur, 2010). The resulting policy expected to handle human trafficking in the Greater Mekong Sub region (GMS). On July 2009, Thailand issued a policy registration process resulting in more expensive new labor permit. Work permit and health insurance for one-year equivalent to a month labor's salary. Although Thailand government already made regulations related to unskilled and low-skilled labor, there are still exist some deviations (Kaur, 2010).

Many low-skilled workers move between countries with invalid documents, illegally, to avoid bureaucracy and high cost. All of ASEAN member countries face this problem except Singapore. In 2009, it is estimated that there are at least 1 million undocumented workers in Malaysia, mostly from neighboring Indonesia but also some from the Philippines (Hugo, 2009). In case of 
Thailand, Myanmar nationals have been migrating undocumented to Thailand where wages are many times higher since 1992 (International Labor Organization (ILO) and Asian Development Bank (ADB), 2014).

In many countries, many types of policy focused on human rights enforcement that related to employment, specifically labor discrimination, child labor and forced labor. ASEAN also has formed Forum on Migrant Labor that has identified three themes summarizing the obligations and commitments in 2008. These themes were (i) protection of migrant workers against exploitation, discrimination, and violence; (ii) labor migration governance; and (iii) fight against trafficking in persons (ASEAN, 2009a). Nevertheless, these policies are not effective yet to regulate all of the labor cases, notably for low-skilled and unskilled labor. Then, many countries renew their laws to stimulate economic growth and trade. They tried to find the effective balance between flexibility, stability and security on migrant labor management (Chalamwong, 2007).

Among other ASEAN countries, Singapore is the only country that can regulate and enforce labor migration policy (Chalamwong \& Rodsomboon, 2007). There is a balance between improving the quality of the economy through the hiring of labor and labor protection in the country. Singapore has successfully regulated labor at various levels, from professionals to low skilled.

Migration in Southeast Asia has three main characteristics. First, international labor migration dominated by temporary workers, mainly low skilled. Second, laborsending countries are promoting and organizing emigration through government- to-government agreements. Third, administrations and responsibilities concerning placement, recruitment and transportation are largely handled by private recruitment agencies, intermediaries, and a migration industry (Kaur, 2010). These three things are raising irregular migration. Mainly migrant workers in ASEAN are low skilled and unskilled. Therefore, by policies that are not strict enough, the number of human trafficking, illegal marriages, prostitution, and worker abuse cases has risen.

AEC primarily concerned with valueadding economic growth, emphasis is placed only on the movement and integration of skilled workers and professionals. With integration such $A E C$, unskilled labor will be affected. Without skills, they will have difficulty to find jobs, and if they can, the available jobs are low paid and of high working hazard. Governments are trying to provide reinforcement to the groups that are not included in productive labor (e.g. women, young children, the elderly, and persons with disabilities) by increasing entrepreneurial capacity to improve their social welfare. Thus, they also can contribute to national development and regional economic integration. ASCC seek social welfare of society, so that the possible negative effects of globalization can be reduced. (ASEAN, 2009b)

ASEAN member countries commit to improve social security. In the progress of enhancing commitments made by the countries, problems of woman employment are persisting. Women usually paid lower than men. Women also face higher challenge after spending time for giving birth, caring 
baby or doing non-paid homework. ASEAN member countries should have additional strategies to ensure social protection of female migrant workers. The countries should promote agreements to ascertain those migrant workers and their families are able to transfer their rights wherever they work (The Ministry of Labour, Invalids and Social Affairs of Vietnam (MoLISA), 2013). There must be enforcement of legislation on wage gap, the adjustment of work and family responsibilities, improve the position of women in leadership and decision making, and social dialogue in gender stereotypes and discrimination. (Serrano et.al., 2013). Upholding women's rights is important because of what they get during their life will affect the development of the next generation (The Ministry of Labor, Invalids and Social Affairs of Vietnam (MoLISA), 2013).

ASEAN's agenda addresses absorption capacity in terms of skills by facilitating the free flow of skilled labor across the region, taking into account relevant domestic regulations and market demand conditions.

(ASEAN Secretariat, 2015). The skilled workers regulated by AEC include engineers, architects, doctors, lawyers and accountants (ASEAN Secretariat, 2015). However, the majority of less-developed countries such as Cambodia, Lao PDR, and Vietnam laborers are farmers, construction workers and factory workers who lack technical skills. In ASEAN, mostly, the right of permanent residence is only granted selectively to skilled migrants. On the other side, majority of emigrants have only primary education, and in less developed countries such as Myanmar, Cambodia and Lao PDR, unskilled migration is significantly higher than skilled migration.

The problem arising is the amount of skilled labor is always less than unskilled labor. Therefore, each ASEAN member country has always had a case of illegal labor migration. The migrant workers are a hero to their country and family. Therefore, the governments should disburse extra budget to equip the workforce with skills needed by market. By the existence of good institutions and labor distributions with affordable cost, illegal workers will be interested to join governments' programs. On the other hand, the governments must actively developing domestic production sector that can absorb many workers. With government labor agency, the labor distribution can take place effectively to meet domestic and international demand of labor. Temporary bilateral cooperation may be undertaken in response to the problems that occurred recently. This cooperation requires good relations between labor-sending country and the labor-receiving country. The policy should have its hand lengthen so it can touch the migrants.

Indeed, the most needed labor supplies for the progress of ASEAN Economic Community are skilled labor, professionals, entrepreneurs, and semi-skilled labor. Still there are many unskilled labor migrates to seek a better wage. Recent regulation has proven ineffective in addressing problems related to unskilled labor. As a result, there are many unpleasant cases related to unskilled migrants. However, there is no assertive policy, which dares to prohibit the movement of unskilled workers abroad. 
Unskilled labors are hard workers. They are the heroes that underestimated. These workers can be empowered in their own country if the domestic industries are developed. Low skilled and unskilled labor can be employed in industrial or home industry. There will be no more cases of human rights violations related to migrants, if the government can provide greater employment opportunities. The Government of each country, especially migrant-exporting countries, should be able to build an industry in each sub region (which is can be build without expensive technology) to provide many jobs. It is not a difficult case if the government really holds their commitment.

In the future, policyholders should add more time to primary education, especially for those who want to work abroad. Now is a good time to take good policy strategies. Good policy can improve the quality of the youth. ASEAN data shows more than half ASEAN population currently aged below 30 years. In case of Indonesia, the 9-year primary education (up to high school level) should added one more year learning time (equivalent diploma-1) to produce graduates who are skillful and insightful. Attempt to equalize the level of basic education and education needed has been listed in ASEAN Socio-Cultural Community Blueprint (ASEAN, 2009b). With appropriate steps, alleviating ASEAN's unskilled labor migration problems will not take a lot of time.

\section{CONCLUSION}

Here are classical but important aspect the government of each country should noted. Countries need to improve working conditions and wages, provide professional training, and improve education for every level of workers. Monitoring the movement of labor from every level and sector are also needed. Job seekers may need information where should they work in an integrated labor market that maximizes criteria and wages they earned. Beside skilled labor market, the integration should provide adequate low-skilled labor market. ASEAN should provide space and special attention to low-skilled workers in the next integration focus. Jobs that require unskilled labor are continually shrinking due to technological and societal advances. Meanwhile, countries are required to provide adequate education for the low-skilled labor in order to enhance the growth of skilled labor to match jobs available.

\section{REFERENCES}

ASEAN Secretariat (2015) ASEAN Integration Report 2015. Jakarta: ASEAN Secretariat.

ASEAN (2009a) ASEAN Committee on the Implementation of the ASEAN Declaration on the Protection and Promotion of the Rights of Migrant Workers (ACMW) Work Plan. ASEAN Secretariat. Accessed from http://www.asean.org/archive/23062.p df on December 19th, 2015.

ASEAN (2009b) ASEAN Socio-Cultural Community Blueprint. Jakarta: ASEAN Secretariat.

ASEAN (2015a) ASEAN Economic Community Blueprint. Jakarta: ASEAN Secretariat.

ASEAN (2015b) Macroeconomic indicator. Accessed from http://www.asean.org/ storage/2015/11/Macroeconomic_Indic ators/T7_Aug15.pdf on December 19th, 2015. 
Battistella, G. and Asis, M. (2003) Unauthorized migration in Southeast Asia. Quezon City: Scalabrini Migration Center.

Chalamwong, Y. and Rodsomboon, S. (2007) "Expanding the Number of Semi-skilled and Skilled Emigrant Workers from Southeast Asia to East Asia". Thailand Development Research Institute Quarterly Review, 3-9.

Das, S.B. (2014) The ASEAN Economic Community's labour policy needs work. Accessed from http://www.straitstimes. com/news/opinion/moreopinionstories/ story/work-needed-asean-communitylabour-policy-20140904 on December $8^{\text {th }}, 2015$.

Hugo, G. (2009) "Best Practice in Temporary Labour Migration for Development: A Prespective from Asia and the Pasific". IOM International Migration, 47(5), 2374.

International Labour Organization (ILO) and Asian Development Bank (ADB) (2014 ASEAN Community 2015: Managing Integration for Better Jobs and Shared Prosperity. Bangkok: ILO and ADB. Accessed from www.adb.org/sites/ default/files/publication/42818/aseanco mmunity-2015-managing-

integration.pdf on November $5^{\text {th }}, 2015$.

Kaur, A. (2006) Order (and Disorder) at The Border: Mobility, International Labour Migration and Border Controls in Southeast Asia. In A. Kaur and I. Metcalfe (Eds.), Mobility Labour Migration and Border Controls in Asia. Basingstoke: Palgrave Macmillan.

Kaur, A. (2010) "Labour Migration Trends and Policy Challenges in Southeast Asia". Journal Policy and Society Associates (APSS), 29, 385-397.

Migration Policy Institute (2013) "International Migrant Population by
Country of Destination, 1960 - 2013". Accessed from www.migrationpolicy.org.

Serrano, M.R., et.al. (2013) Labour Laws and Practices : A Comparative Study on Gender Equality, Employment of Persons with Disabilities, Youth Employment and Social Dialogue (Volume 2). Jakarta: ASEAN Service Employees Trade Union Council.

The Ministry of Labor, Invalids and Social Affairs of Vietnam (MoLISA) (2013) Maternity Protection for Female Workers: Laws and Practices in ASEAN. Vietnam.

The Straits Times (2009) Maid Talks Delayed, July $13^{\text {th }}, 2009$.

World Bank (2013) "Immigration (in), Emigration (out), and Net Migration Flows for Countries ASEAN in 2013". Data. Accesed from www.data.worldbank.org.

World Bank (2014) "Bilateral Remittance Matrix 2014". Data. Accessed from www.econ.worldbank.org.

Yeoh, B.S.A. and Lin, W. (2012) Rapid Growth in Singapore's Immigrant Population Brings Policy Challenges. Accessed from http://www.migrationpolicy.org/article/ rapid-growth-singapores-immigrantpopulation-brings-policy-challenges/ on December 19th 2015.

Yeoh, B.S.A. and Mirriam, E. (2014) Labour Migration and Integration in ASEAN. Migration and Integration: Common Challenges and Responses from Europe and Asia. Singapore: Konrad Adenauer Stiftung. Accessed from http://www.kas.de/wf/doc/kas_405621522-2-30.pdf?150227063413.

Zachariadis, M. (2012) "Immigration and International Prices". Journal of International Economics, 87(2), 298-311. 